\title{
Effect of adhesive replacement with cement mortar on NSM strengthened RC Beam
}

\section{Efecto de la sustitución de adhesivo con mortero de cemento en Viga NSM de Hormigon Reforzado fortalecida}

\author{
Md. Moshiur Rahman (Main Author) \\ Department of Civil Engineering, Faculty of Engineering, University of Malaya, 50603, Kuala Lumpur, Malaysia. \\ moshiur72@siswa.um.edu.my
}

\section{Mohd Zamin Jumat (Corresponding Author)}

Department of Civil Engineering, Faculty of Engineering, University of Malaya, 50603, Kuala Lumpur, Malaysia. zamin@um.edu.my

\section{Md. Akter Hosen}

Department of Civil Engineering, Faculty of Engineering, University of Malaya, 50603, Kuala Lumpur, Malaysia. akter@siswa.um.edu.my

\section{A. B. M. Saiful Islam}

Department of Construction Engineering, College of Engineering, University of Dammam, 31451, Dammam, Saudi Arabia. asislam@uod.edu.sa

\begin{abstract}
This paper presents the experimental behavior of reinforcement concrete beams strengthened with near surface mounted (NSM) steel bar. Several researchers have used NSM fiber reinforced polymer (FPR) bar or strip for strengthening reinforced concrete beams. Though FRP has a number advantages like high strength, light weight and corrosion resistance it doesn't show any ductile behavior, still highly expensive and not easily available in market. On the other hand, steel bar is less expensive, readily available in the market and shows good ductility. In order to get rapid and economic strengthening solution, strengthening with near surface mounted steel bar may become a potential alternative to retrofit reinforced concrete members. Therefore, the main purpose of this paper to investigate the experimental behavior of reinforced concrete beam strengthened with near surface mounted steel bar. Seven full-size beams (one control beams and six strengthened beams) were tested. Steel bars were used for strengthening. The failure load, mode of failure, deflection, and strain behavior are discussed. The study reveals that the near surface mounted technique with steel bars and cement mortar is the most economical strengthening solution to increase the flexural performance of RC beams.
\end{abstract}

Keyword: Strengthening, Near surface mounting, Steel bar, Reinforced concrete, Low cost strengthening materials, Cement mortar.

\section{Resúmen}

En este trabajo se presenta el comportamiento experimental con mortero de cemento en Viga NSM de Hormigon Reforzado fortalecida. Varios investigadores han utilizado barra o tiras de NSM (montaje cercano a la superficie) de FRP (polímero reforzado con fibra) para el fortalecimiento de vigas de hormigón armado. Aunque FRP tiene un número de ventajas como alta resistencia, ligereza y resistencia a la corrosión, no muestra ningún comportamiento dúctil, siendo muy caros y no están fácilmente disponibles en el mercado. Por otro lado, la barra de acero es menos costosa, fácilmente disponible en el mercado y muestra una buena ductilidad. Con el fin de obtener una solución rápida y económica, el fortalecimiento con barra de acero NSM puede llegar a ser una alternativa potencial para adaptar los miembros de hormigón armado. Por lo tanto, el objetivo principal de este trabajo para investigar el comportamiento experimental de las vigas de hormigón armado reforzado con barras de acero NSM. Se ensayaron siete vigas de tamaño completo (una viga de control y seis vigas reforzadas). Barras de acero se utilizaron para el fortalecimiento. La carga de rotura, modo de fallo, deformación, y el comportamiento de tensión se discuten. El estudio revela que la técnica NSM con barras de acero y mortero de cemento es la solución de fortalecimiento más económica para aumentar el rendimiento de flexión de vigas RC.

Palabras Claves: Fortalecimiento, montaje en superficie cercana, barras de acero, hormigón armado, materiales de fortalecimiento de bajo coste, mortero de cemento.

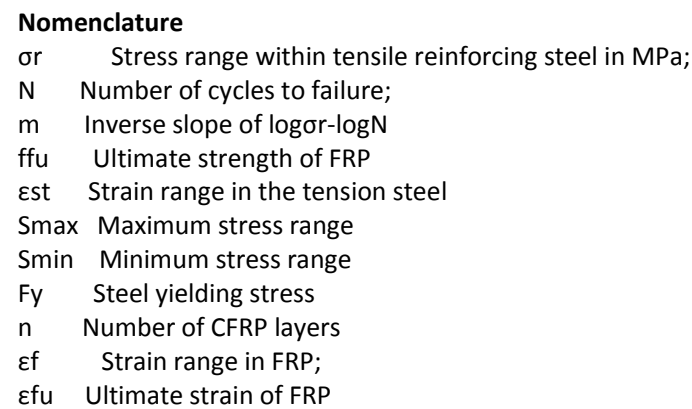


Strengthening of structures is required for numerous reasons like as extension of design life, functional change, mechanical damage and environmental effects, updated design requirements, errors due to design and construction(Cárdenas, Schanack, \& Ramos, 2010; Toutanji, Zhao, \& Zhang, 2006). It is both environmentally and economically desirable to upgrade structures rather than rebuild them, particularly if rapid, effective and simple strengthening methods are available (Aldana \& Serpell, 2012; Islam, Jameel, Jumaat, \& Rahman, 2013; Yue-lin, Jong-hwei, Tsong, Chien-hsing, \& Yiching, 2005). There are many methods available for strengthening existing deficient structure among which external plate bonding method and near surface mounted technique are the most popular (Bilotta, Ceroni, Nigro, \& Pecce, 2015; Hosen, Jumaat, \& Islam, 2015; Rahman, Jumaat, Rahman, \& Qeshta, 2015).

The bonded steel plates or carbon fiber reinforced polymer (CFRP) plates to soffit of reinforced concrete structures to increase its strength or serviceability has been utilized worldwide since the late 1960s. However, the development of high interfacial shear stresses at the plate ends could cause the premature debonding failure without utilizing its full capacity. More recently, nearsurface mounted (NSM) reinforcement has attracted an increasing amount of research as well as practical application because it is less prone to premature debonding (De Lorenzis \& Teng, 2007).

Though FRP has a number advantages like high strength, light weight and corrosion resistance, however it is still highly expensive and less available in market. Moreover, FRP expresses less ductile behavior. On the other hand, steel bar is less expensive, readily available in the market and their long-term durability and bond performance has been thoroughly researched (Rahal \& Rumaih, 2011). And, it's also shows sufficient ductility. In order to rapid and economic strengthening solution, strengthening with near surface mounted steel bar may become a potential alternative to retrofit reinforced concrete member.

The use of NSM steel bars were started in Europe for strengthening of RC structures since early fifties (Lorenzis, 2002). The earliest reference that could be found in the literature dates back to 1949(Asplund, 1949)) where steel rebar with cement morter was used to strengthen a concrete slab in the field construction work. More recent applications of NSM stainless steel bars for the strengthening of masonry buildings and arch bridges have also been documented (Garrity, 2001; Wang, Jin, Cleland, \& Zhang, 2009).

Most of experimental study was conducted to investigate the flexural behavior of reinforced concrete beam with NSM-FRP bar (AlMahmoud, Castel, François, \& Tourneur, 2009; Badawi \& Soudki, 2009; De Lorenzis, Nanni, \& Tegola, 2000; El-Hacha \& Gaafar, 2011; El-Hacha \& Rizkalla, 2004; Soliman, El-Salakawy, \& Benmokrane, 2010) or strip (El-Hacha and Rizkalla, 2004). The test results confirm that NSM FRP rods can be used to significantly increase the flexural capacity of RC elements. Little or so far no experimental investigations was found on the flexure performance of concrete beam with NSM steel bar.

In order to realize the effectiveness of strengthening using NSM steel bar, the structural behavior of RC elements strengthened with NSM steel bar to be fully characterized. Seven medium-size beams (one control beams and six beams strengthened in flexure with NSM steel rods) were tested in this study. The examined variables were adhesive type, the partial replacement of epoxy adhesive with cement mortar, number of NSM groove, amount of reinforcement and its disposition. Performance of the tested beams and modes of failure are presented and discussed in this paper. The test results show that strengthening with NSM steel bar is also effective and economic strengthening technique.

Description of the problem

The strengthening materials like fiber reinforced polymer (FRP) bars and adhesive (epoxy) are very expensive and not available in the global market. However, FRP bars shows very few ductility performance. Alternate rapid and economic strengthening technique is very essential and NSM steel reinforcing approach may fill the necessity suitably.

An experimental program has been arranged to verify the effectiveness of strengthening technique with NSM steel bar. Experimental data on load, deflection, strains and failure mode was obtained. The experimental program consisted of seven RC beams. In this section, a description of material used, the test specimen and its different fabrication stages, the procedure used to strengthen the RC beams; the instrumentations and the test-setup are provided.

\section{Material used and its properties \\ Concrete}

The Ordinary Portland Cement (OPC) was used in casting the beams. The cement was used as a binding materials. The crushed granite (Stone) was used as coarse aggregate and the maximum size of coarse aggregate was $20 \mathrm{~mm}$. It was sieved through $3 / 16^{\prime}$ sieve and air-dried in the concrete laboratory. The natural river sand was used as fine aggregate. Fresh tap water was used for the hydration of the concrete mix during casting and curing of the beam, cubes, prism and cylinders. The concrete mix was designed for $30 \mathrm{MPa}$ strength using DOE method. 


\section{Reinforcement}

Three types of steel bars were used in this research for preparation of the beam specimen. The measured yield and tensile strength of $12 \mathrm{~mm}$ bars were $551 \mathrm{MPa}$ and $641 \mathrm{MPa}$ respectively. The flexure reinforcement were bent 90 (ninety) degree at both end to fulfill the anchorage criteria according to BS8110. Ten millimeter diameter bars were used as hanger bars in shear span zone. Six $\mathrm{mm}$ diameter bars were used for stirrups. The measured yield and tensile strength of the stirrups were $520 \mathrm{MPa}$ and $572 \mathrm{MPa}$ respectively. Six $\mathrm{mm}$ bars were also used for strengthening purpose in NSM strengthening system. Besides six $\mathrm{mm}$ bar, eight $\mathrm{mm}$ deformed bars were used to strengthened RC beam particularly in NSM groove. The modulus of elasticity of all steel bars was 200 GPa.

\section{Cement mortar and epoxy}

The use of cement paste or mortar in place of epoxy as a groove filler has recently been explored in an attempt to lower the material cost, reduce the hazard to workers, minimize the environmental impact, allow effective bonding to wet substrates, and achieve better resistance to high temperatures and improved thermal compatibility with the concrete substrate(De Lorenzis \& Teng, 2007). However, the very limited data is available on use of cement mortar as groove filler in NSM strengthening technique. It is therefore decided to use cement mortar as groove filler for strengthening RC beam using NSM technique. $50 \%$ cement and $50 \%$ sand were mixed with water cement ratio of 0.5 to produce cement mortar.

To compare the performance of cement mortar with epoxy adhesive, Sikadur ${ }^{\circledR} 30$ was used as adhesive for bonding between concrete substrate and strengthening materials. It has two component namely component $A$ and $B$. The color of the component $A$ was white while the color of $B$ was black. The two components were mixed with a ratio of 3:1 until the the uniform colour of grey was achieved. Density would be $1.65 \mathrm{~kg} / \mathrm{liter}$ at $230 \mathrm{c}$ after mixing. The bond strength on steel is $21 \mathrm{~N} / \mathrm{mm} 2$ according to DIN EN 24624 and on concrete is $4 \mathrm{~N} / \mathrm{mm} 2$. The compressive, tensile and shear strength of this adhesive vary with curing time and temperature that is shown in Table 1.

Table 1: Properties of Sikadur ${ }^{\circledR}$ 30. Source: Self-Elaboration (2015)

\begin{tabular}{|l|l|l|}
\hline Strength & $15^{0} \mathrm{c}$ & $35^{0} \mathrm{c}$ \\
\hline Compressive strength & $70-80 \mathrm{~N} / \mathrm{mm}^{2}$ & $85-95 \mathrm{~N} / \mathrm{mm}^{2}$ \\
\hline Tensile strength & $14-17 \mathrm{~N} / \mathrm{mm}^{2}$ & $16-19 \mathrm{~N} / \mathrm{mm}^{2}$ \\
\hline Shear strenth & $24-27 \mathrm{~N} / \mathrm{mm}^{2}$ & $26-31 \mathrm{~N} / \mathrm{mm}^{2}$ \\
\hline
\end{tabular}

\section{Beam design and preparation}

All beam specimens were $2300 \mathrm{~mm}$ long, $125 \mathrm{~mm}$ wide, and $250 \mathrm{~mm}$ deep as shown in Figure 1 . These beams were reinforced with two $12 \mathrm{~mm}$ diameter steel bars in the tension zone as main reinforcement. Two $10 \mathrm{~mm}$ steel bars were used as hanger bars in the shear span and were placed at the top of each beam. Six $\mathrm{mm}$ bars were used for shear reinforcement and were symmetrically placed in the shear span. A typical concrete cover of $30 \mathrm{~mm}$ was used. Enough shear reinforcement was provided in an amount calculated to ensure that the beams would fail in flexure.

The cement, sand, coarse aggregate and water with proper amount were mixed using laboratory drum mixer. For casting, steel moulds made of steel were used. Before placing the concrete the steel moulds were cleaned and greased. After placing the concrete was compacted by poker vibrator. The beams were cast in three layers, where each layer was compacted using poker vibrator to ensure adequate compaction. During vibration process, each penetration was made at a reasonable distance from each other to avoid the bleeding and segregation of concrete.

Fig. 1: Details of beam specimen. Source: Self-Elaboration (2015)

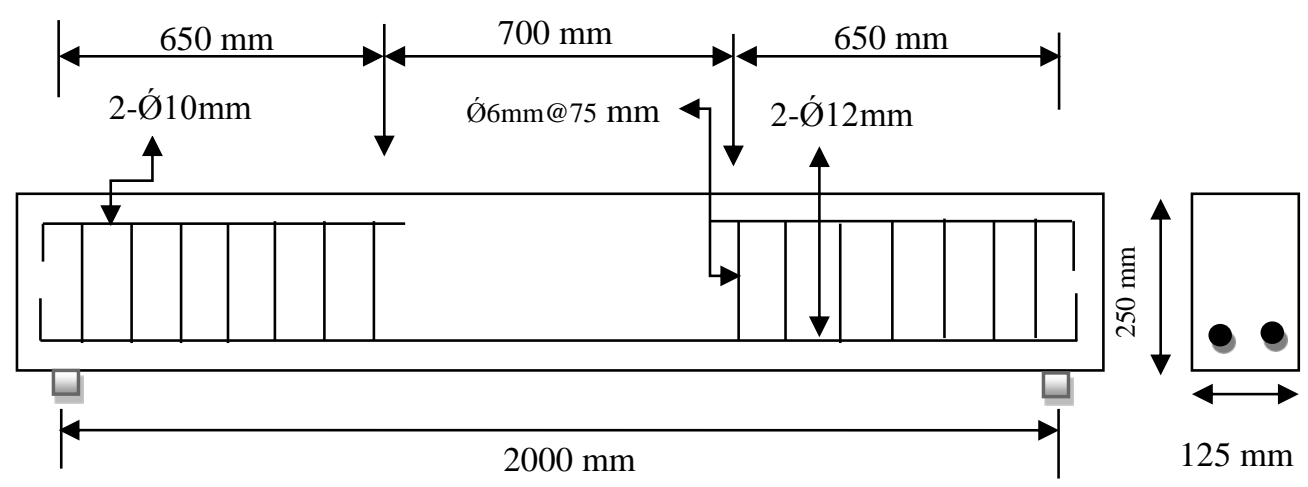




\section{Strengthening of RC beams \\ Groove Cutting}

In NSM technique, grooves are first cut into the concrete cover of an RC element and the FRP reinforcement is bonded therein with an appropriate groove filler. A special concrete saw was used to cut the grooves at the bottom surface of the beam. The groove dimensions were $10 \mathrm{~mm}$ wide by $15 \mathrm{~mm}$ deep.

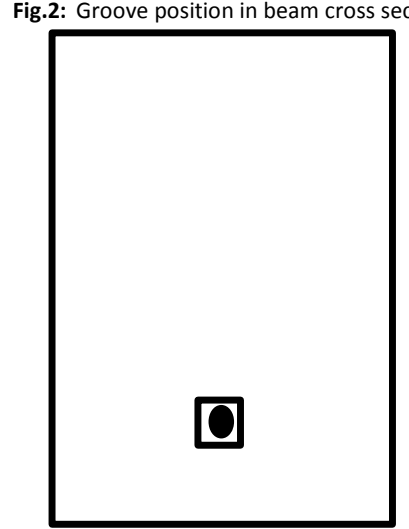

NS4, NS5

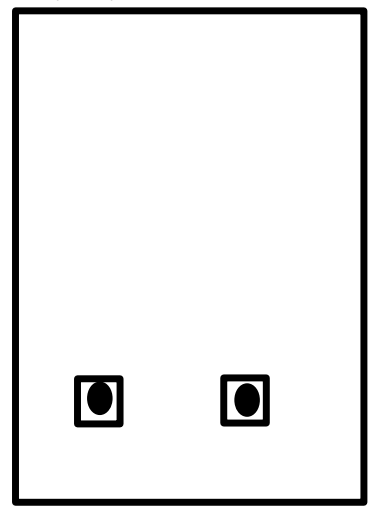

NS1, NS2, NS3

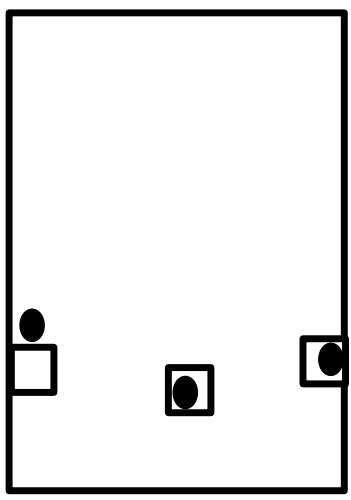

NS6

After groove cutting and surface preparation, prepared specimen for strengthening is shown in Fig. 3.

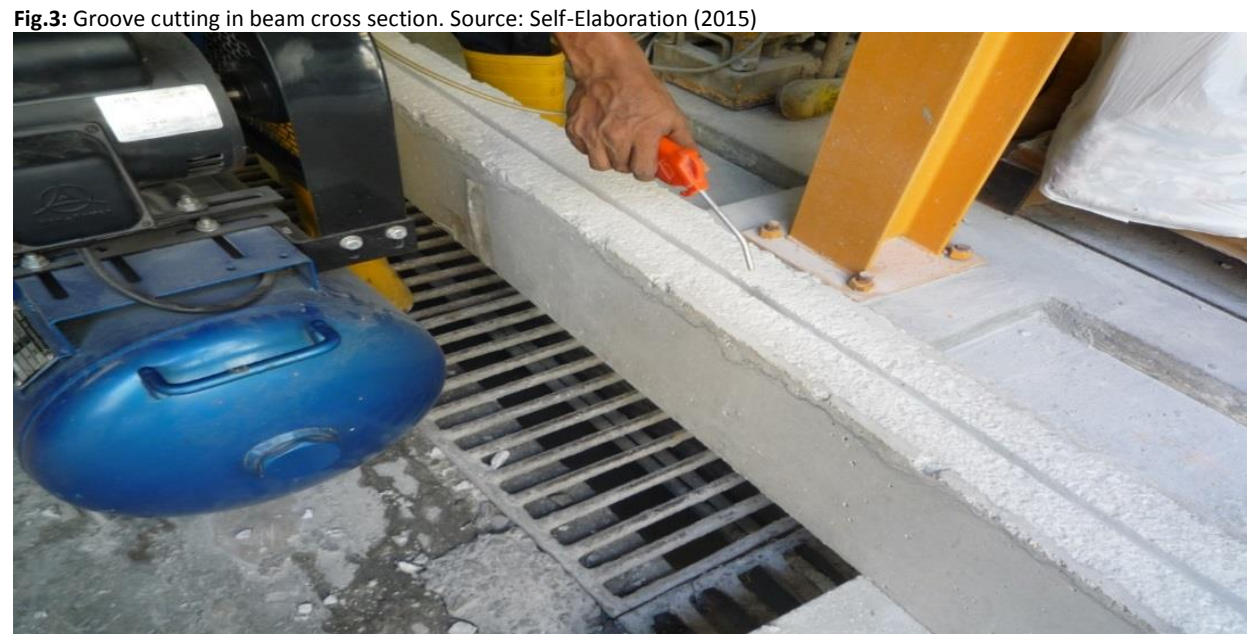

\section{Placement of steel bar}

The properly mixed Sikadur/cement mortar was then spread over NSM groove of concrete surface. The groove was half filled with epoxy/cement mortar and the steel bars were placed and pressed into the center of the groove. Then, the remaining space in the groove was completely filled with epoxy/cement mortar. The epoxy/cement mortar was leveled with a spatula and cured for at least seven days before testing.

\section{Instrumentation and test setup}

Linear Variable Differential Transducer (LVDT) with working transverse range of $50 \mathrm{~mm}$ was used to measure the deflection of the beam at mid span. The transducer was connected to a portable data logger to record the reading of the deflection of the beam during test. In addition to LVDT, the actuator position of Instron Universal Testing Machine was monitored to measure the deflections at the midspan of all beams particularly to avoid the damage of the LVDT after initiating the failure of the beam. These information are useful to understand the deformability or ductility behavior of both un-strengthened and strengthened beam.

Electrical resistance strain gauges measured the strains in the steel bar and the concrete. The internal tension steel rebars were grinded by mechanical grinder at mid span. After grinding, the surface was cleaned by acetone to remove dust particles. Two $5 \mathrm{~mm}$ gauge were then attached to the middle of internal reinforcing bars by fast setting adhesive on top or bottom face two main steel rebars to record the tension strain. 
Silicon was applied on the strain gauge as well as necked wire for proper water sealing. Two $30 \mathrm{~mm}$ strain gauges were placed at the middle of top face of concrete beam and bottom of the strengthening the steel/FRP plate to measure the concrete compressive and plate tensile strain. The data logger was also connected with the digital controller of the testing machine and strain gauges attached to the beams, for collecting the real-time loading and strains at the top concrete surface and bottom plate surface. The readings are scanned at a time interval of 1 (one) second.

All beams were tested in four-point bending and the tests were conducted with a closed-loop hydraulic Instron Universal Testing Machine. All specimens were simply supported and were subjected to two-point loading. The distance between two supports was $2000 \mathrm{~mm}$ and the distance between two loading points of spreader beam was 700.The resulting shear span/depth ratio was 3.0. For the static load test the actuator was loaded and moved down at a low rate so that reading from the data logger and visibility of crack can be done easily. Test matrix are shown in Table 2

Table 2: Test matrix. Source: Self-Elaboration (2015)

\begin{tabular}{|l|l|l|l|}
\hline SI. No & Notation & Description & Dimension of strengthening (mm) \\
\hline 1 & CB & Control Beam & No strengthening \\
\hline 2 & NS1 & Beam strengthened with cement mortar and two steel plain bar & $\begin{array}{l}\text { Steel bar dia-6 mm } \\
\text { Length=1900 }\end{array}$ \\
\hline 3 & NS2 & Beam strengthened with epoxy adhesive and two steel plain bar & $\begin{array}{l}\text { Steel bar-6 } \mathrm{mm} \\
\text { Length=1900 }\end{array}$ \\
\hline 4 & NS3 & $\begin{array}{l}\text { Beam strengthened with epoxy(end) and cement mortar (middle) and two } \\
\text { plain steel bar }\end{array}$ & $\begin{array}{l}\text { Steel bar-6 } \mathrm{mm} \\
\text { Length=1900mm }\end{array}$ \\
\hline 5 & NS4 & $\begin{array}{l}\text { Beam strengthened with epoxy and one steel deformed bar } \\
\text { Steel bar--8 } \mathrm{mm} \\
\text { Length-1900 mm }\end{array}$ \\
\hline 6 & HS5 & $\begin{array}{l}\text { Damage Beam strengthened with cement mortar and one steel deformed } \\
\text { bar }\end{array}$ & $\begin{array}{l}\text { Steel bar-8 } \mathrm{mm} \\
\text { Length-1900mm }\end{array}$ \\
\hline 7 & HS6 & $\begin{array}{l}\text { Beam strengthened with cement mortar and three(two side and one } \\
\text { bottom) steel deformed bar }\end{array}$ & $\begin{array}{l}\text { Steel bar-8 } \mathrm{mm} \\
\text { Length=1900 } \mathrm{mm}\end{array}$ \\
\hline
\end{tabular}

Result and discussion

\section{Experimental behavior of strengthened beams Load carrying capacity and failure mode}

A summary of the flexural behavior of all test beams in terms of first crack load, yield load, flexural loading capacity and failure mode has been given in Table 3. As shown in Table 3, the addition of steel bar and steel plate increases the ultimate moment capacity by $22.5 \%, 46.8 \%, 43.75 \%, 26.46 \%, 23.26 \%$ and $32.8 \%$ for NS1, NS2, NS3, NS4, NS5 and HS6 respectively, compared to the control beam. Yield capacity of the beam and first cracking loading also increased after strengthening. It is important to note that the highest improvement achieved in NS2 was $46.8 \%$ which is also greater than the performance (39\%) of NSM FRP strengthened concrete beam studied by eHassan and Rizkalla (2001) though the cost of FRP bar is 20 times greater than that of steel bar.

Table 3: load and mode, yield load, first cracking load of different beams. Source: Self-Elaboration (2015)

Table 3: load and mode, yield load, first cracking load of different beams. Source: Self-Elaboration (2015)
\begin{tabular}{|l|l|l|l|l|l|l|}
\hline Beam ID & $\begin{array}{l}\text { First crack } \\
\text { load }\end{array}$ & $\begin{array}{l}\text { First crack load } \\
\text { increase } \\
\text { control beam }\end{array}$ & $\begin{array}{l}\text { Bar yield } \\
\text { load }\end{array}$ & Failure load & $\begin{array}{l}\text { Failure load increase } \\
\text { over Control beam }\end{array}$ & Mode of failure \\
\hline CB & 12.5 & - & 72 & 80 & & Flexure failure \\
\hline NS1 & 20 & $62.5 \%$ & 90 & 98 & $22.5 \%$ & $\begin{array}{l}\text { Flexure failure followed by bond } \\
\text { failure }\end{array}$ \\
\hline NS2 & 26 & $112.5 \%$ & 100 & 117.44 & $46.8 \%$ & Flexure failure \\
\hline NS3 & 22 & $79.17 \%$ & 92 & 115.00 & $43.75 \%$ & Flexure failure \\
\hline NS4 & 28 & $129.17 \%$ & 100 & 101.17 & $26.46 \%$ & Flexure failure \\
\hline NS5 & Pre-cracked & - & 90 & 98.00 & $22.5 \%$ & $\begin{array}{l}\text { Flexure failure followed by bond } \\
\text { failure. }\end{array}$ \\
\hline NS6 & 25 & $104.17 \%$ & 100 & 106.24 & $32.8 \%$ & Debonding failure \\
\hline
\end{tabular}

The failure modes of all beams are shown in Figure 4. The failure modes of all strengthened beam are found very close to each other i.e. flexure failure. Flexure failure is concrete crushing followed by steel yielding. It is the most commonly reported mode of failure in NSM strengthening system. It is less prone to debonding. However, the failure mode of the most heavily reinforced beam NS6 was premature debonding i.e. the separation of steel bar from concrete side face. 

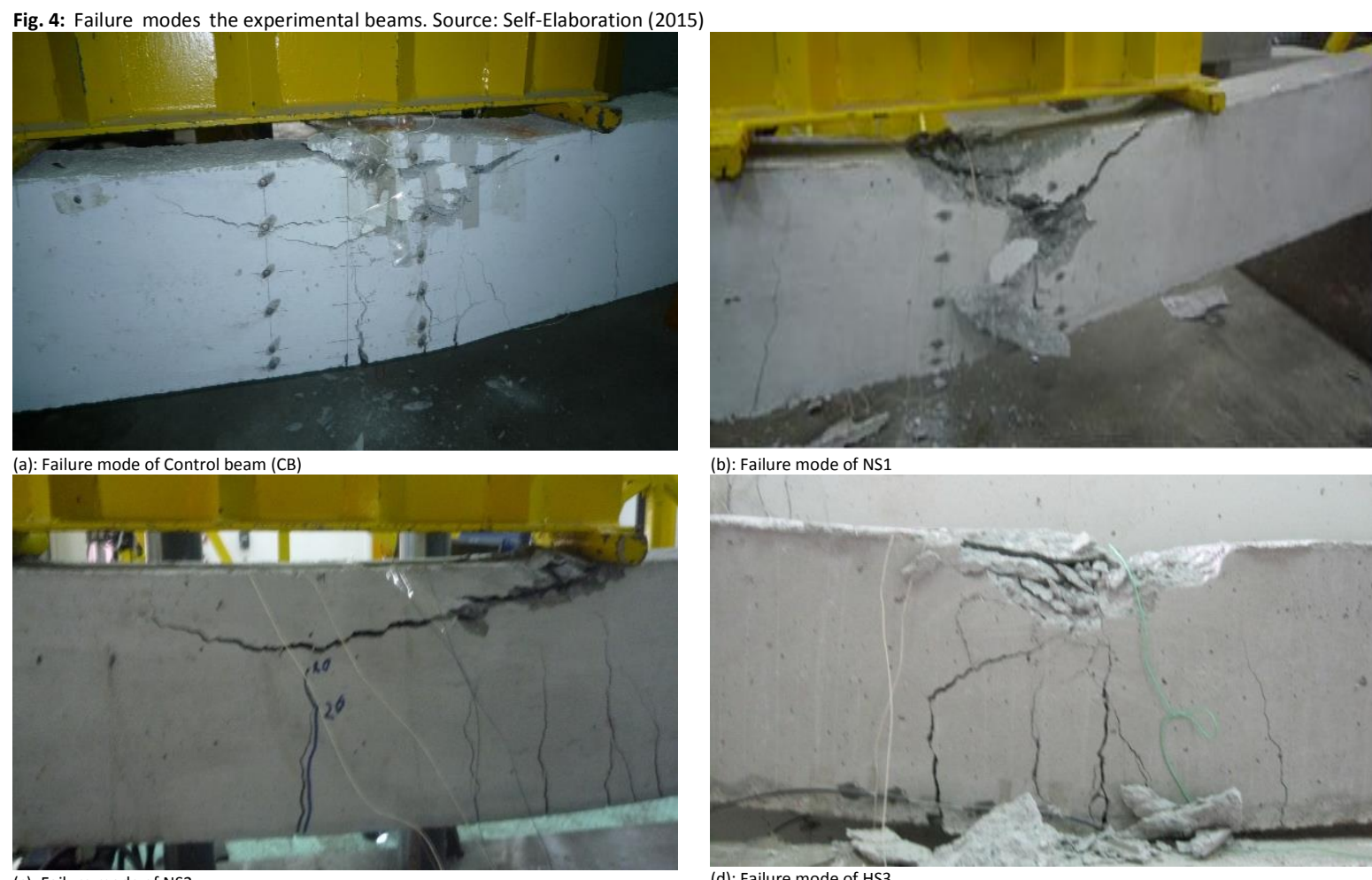

(b): Failure mode of NS1
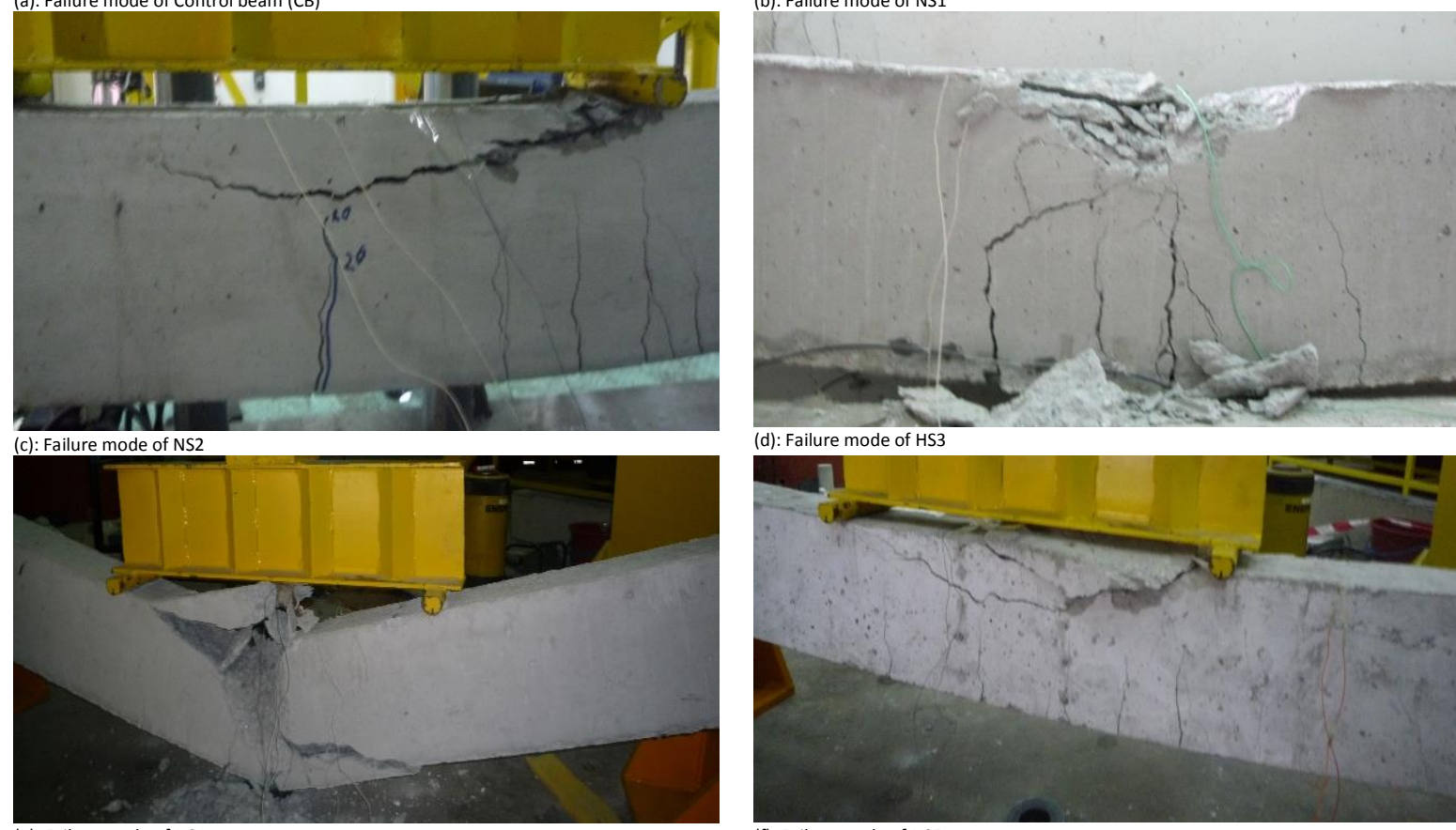

(d): Failure mode of HS3
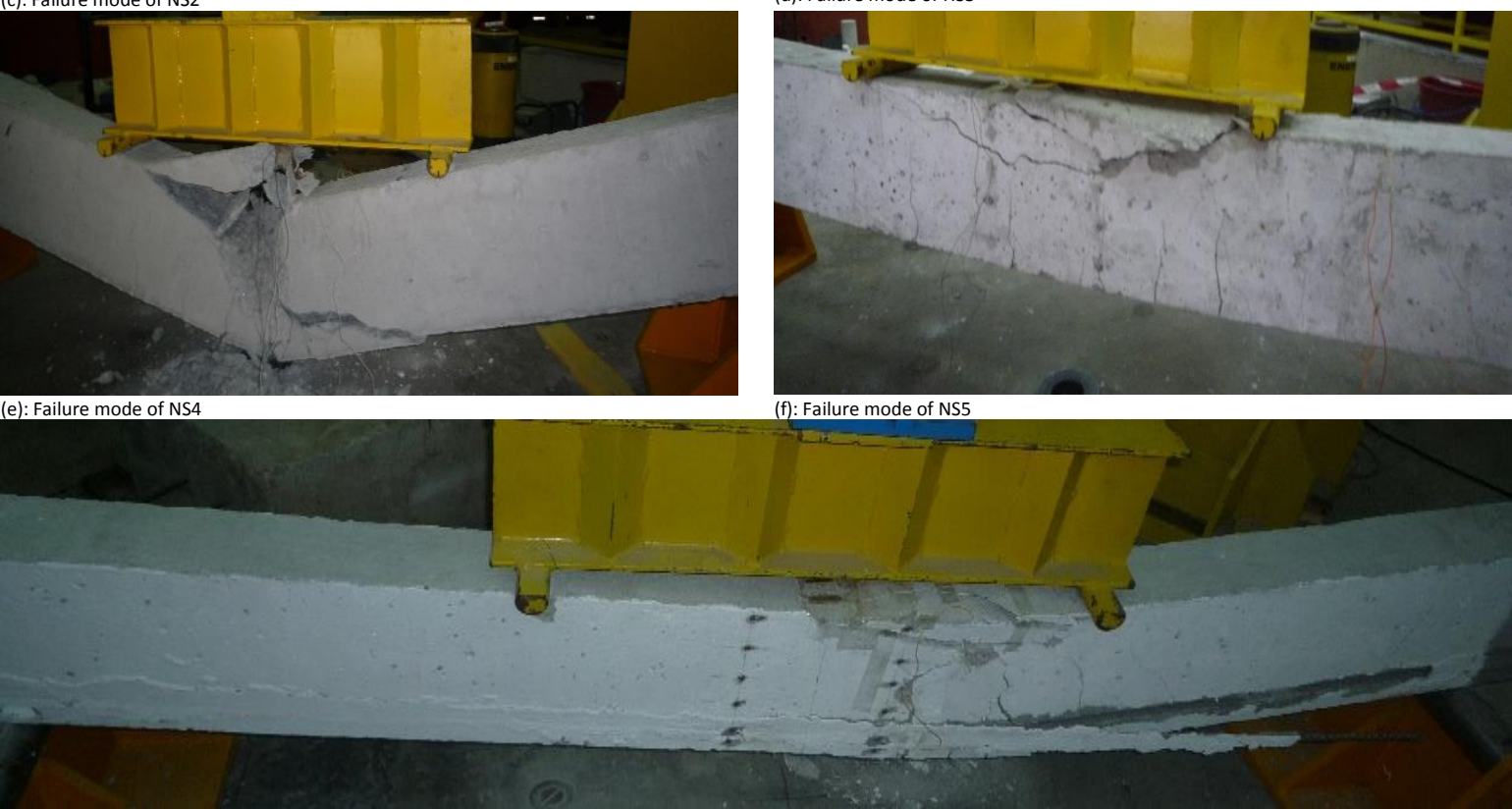

(f): Failure mode of NS5

(g): Failure mode of NS6

\section{Effect of strengthening on damage behavior}

The deflection and reduction of deflection due to strengthening hybrid technique at $20 \mathrm{KN}, 40 \mathrm{KN}, 60 \mathrm{KN}$ service loadings are shown in table 4. The deflection of strengthened beams were reduced compared to control beam because the stiffness of strengthened beam increased due to addition of strengthening materials like NSM steel bar.

Table 4: Reduction in Deflection due to NSM strengthening. Source: Self-Elaboration (2015)

\begin{tabular}{|l|l|l|l|l|l|l|}
\hline \multirow{2}{*}{ Beam No. } & Load at 20 & Deflection & $\begin{array}{l}\text { Reduction (\%) } \\
\text { over CB }\end{array}$ & Deflection & $\begin{array}{l}\text { Reduction (\%) } \\
\text { over CB }\end{array}$ & Load at 60 \\
\hline CB & 2.42 & & 5.51 & & 8.48 & \\
Deflection & & \\
NS1 & 1.48 & $39 \%$ & 3.71 & $33 \%$ & 5.01 & $41 \%$ \\
\hline NS2 & 1.55 & $36 \%$ & 3.23 & $41 \%$ & 5.26 & $38 \%$ \\
\hline NS3 & 1.81 & $25 \%$ & 3.69 & $33 \%$ & 5.47 & $35 \%$ \\
\hline NS4 & 2.61 & - & 5.48 & $1 \%$ & 7.833 & $8 \%$ \\
\hline NS5 & 3.86 & $-60 \%$ & 5.17 & $6 \%$ & 6.81 & $20 \%$ \\
\hline NS6 & 1.39 & $43 \%$ & 3.12 & $43 \%$ & 6.94 & $18 \%$ \\
\hline
\end{tabular}


The internal reinforcing steel bar strain and reduction of these bar strain due to strengthening at $20 \mathrm{KN}, 40 \mathrm{KN}, 60 \mathrm{KN}$ service loading are shown in Table 5. The bar strain of strengthened beams was reduced significantly. Consequently the bar stress would also be reduced according hook's law. Therefore, the fatigue life of strengthened beam will be increased according S-N curve relation of steel bar (Helagson \& Hanson, 1974; Moss, 1982). However, difference in bar strain reduction between hybrid and plate bonding method were not noticed clearly.

Table 5: Reduction in Bar Strain due to NSM strengthening. Source: Self-Elaboration (2015)
\begin{tabular}{|l|l|l|l|l|l|l|}
\hline \multirow{2}{*}{ Beam No. } & Load at 20 & Load at 40 & Load at 60 & \\
\cline { 2 - 8 } & Bar Strain & $\begin{array}{l}\text { Reduction } \\
\text { over CB }\end{array}$ & Bar Strain & $\begin{array}{l}\text { Reduction (\%) } \\
\text { over CB }\end{array}$ & Bar Strain & $\begin{array}{l}\text { Reduction (\%) } \\
\text { over CB }\end{array}$ \\
\hline CB & 793 & & 1661 & & 2507 & \\
\hline NS1 & 556 & $30 \%$ & 1059 & $36 \%$ & 1509 & $40 \%$ \\
\hline NS3 & 248 & $69 \%$ & 1465 & $12 \%$ & 3006 & $-20 \%$ \\
\hline NS4 & 406 & $49 \%$ & 1528 & $8 \%$ & 2418 & $4 \%$ \\
\hline NS6 & - & & 933 & $44 \%$ & 1523 & $39 \%$ \\
\hline
\end{tabular}

The strain at top of concrete fiber and reduction of these concrete strain due to strengthening at $20 \mathrm{KN}, 40 \mathrm{KN}, 60 \mathrm{KN}$ service loading are shown in table 6 . The extreme concrete strain of strengthened beams was reduced significantly.

Table 6: Reduction in Concrete Strain due to NSM strengthening. Source: Self-Elaboration (2015)

\begin{tabular}{|c|c|c|c|c|c|c|}
\hline \multirow[b]{2}{*}{ Beam No. } & \multicolumn{2}{|l|}{ Load at 20} & \multicolumn{2}{|l|}{ Load at 40} & \multicolumn{2}{|l|}{ Load at 60} \\
\hline & Con. Strain & $\begin{array}{l}\text { Reduction (\%) } \\
\text { over CB }\end{array}$ & Con. Strain & $\begin{array}{l}\text { Reduction (\%) } \\
\text { over } \mathrm{CB}\end{array}$ & Con. Strain & $\begin{array}{l}\text { Reduction } \\
\text { over CB }\end{array}$ \\
\hline$C B$ & 252 & & 602 & & 990 & \\
\hline NS1 & 175 & $31 \%$ & 376 & $38 \%$ & 510 & $48 \%$ \\
\hline NS2 & 126 & $50 \%$ & 337 & $44 \%$ & 542 & $45 \%$ \\
\hline NS5 & 200 & $21 \%$ & 383 & $36 \%$ & 550 & $44 \%$ \\
\hline NS6 & - & & 450 & $25 \%$ & 697 & $30 \%$ \\
\hline
\end{tabular}

\section{Parametric study}

\section{Effect of adhesive type}

The effect of adhesive type on the performance of NSM strengthened RC beam is shown in Table 3. Based on experimental data of NS1 and NS2, as the adhesive type changed from cement mortar to epoxy, the failure load also increased from $98 \mathrm{kN}$ to $117.44 \mathrm{kN}$ which is usual behavior because bonding strength of epoxy is significantly higher than that of cement mortar. First crack load also increased from $20 \mathrm{kN}$ to $26 \mathrm{kN}$ due to change of adhesive type. The load deflection behavior of CB, NS1 and NS2 are shown in Fig.5a. The NS2 shows less deflection compared with NS1 owing to higher mechanical properties of adhesive. 


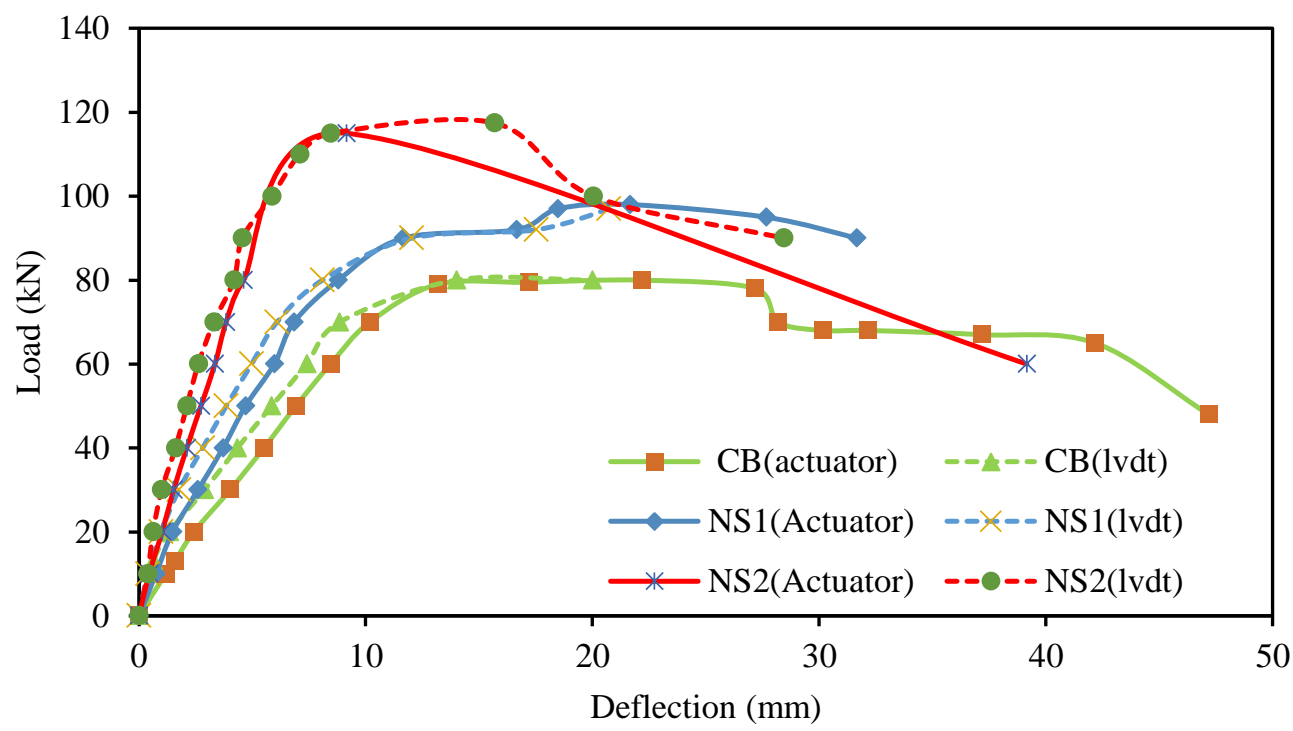

$5(a)$

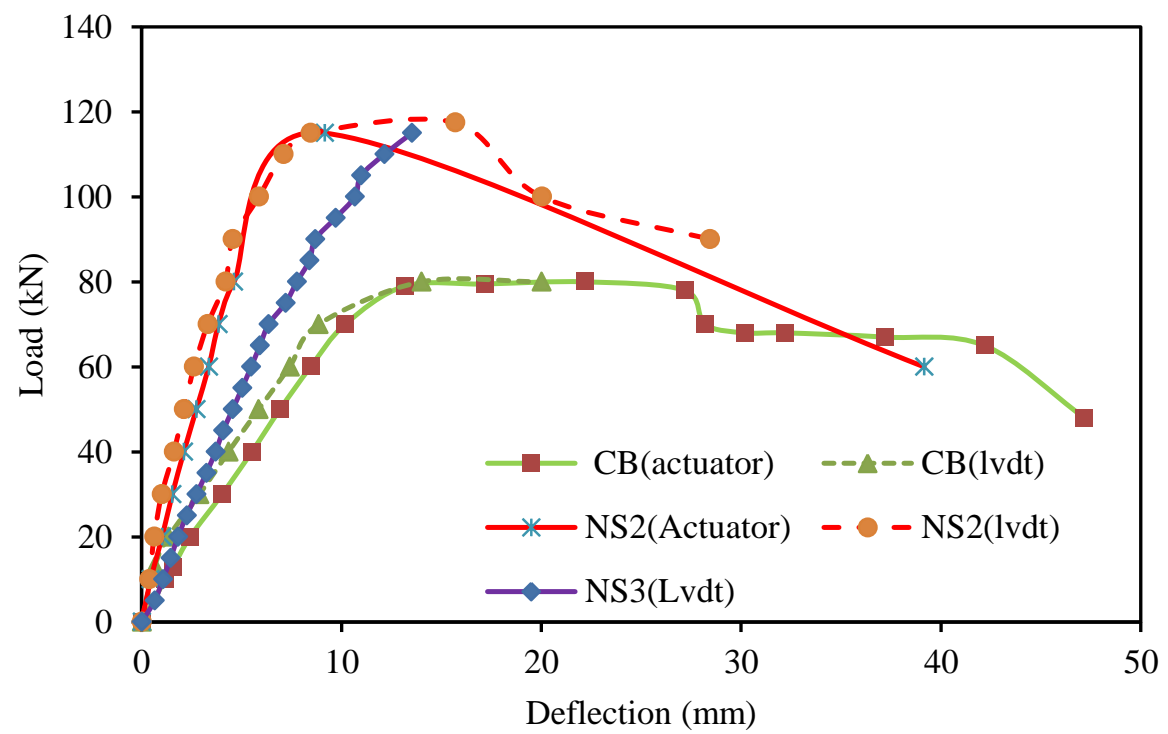

5(b)

\section{Effect of partial epoxy replacement with cement mortar}

Cement mortar mechanical properties, durability, and tensile strength lower than of commercially available epoxies (De Lorenzis \& Teng, 2007). Results of bond tests and flexural tests (Taljsten, Carolin, \& Nordin, 2003) have identified some significant limitations of cement mortar as a groove filler. However, the bond stresses are not equally distributed along the length of NSM bar according to De Lorenzis and Teng (2007). The maximum bond stress is found near end of the NSM bar and it gradually decrease towards the mid span of beam. This characteristic of bond stress variation may attribute the partial replacement of epoxy with cement mortar. Since the bond stress of mid-section of beam is relatively low, the NSM groove at these locations could be filled with cement mortar. However at the other location, particularly at the end, the groove should be filled with epoxy adhesive due to higher bond stress. The stiffness of NS3 is slightly lower than that of NS2, since the deflection of NS3 is higher than NS2 as shown in Fig. $5 \mathrm{~b}$.The effect of partial replacement of epoxy with cement mortar is shown in Fig 6. The ultimate load of NS3 (50\% epoxy replaced with cement mortar) is almost similar to the ultimate load of NS2 (epoxy is used entirely) but significantly higher than that of NS1 (cement mortar is used entirely). 
Fig. 6: The effect of partial replacement of epoxy with cement mortar. Source: Self-Elaboration (2015)

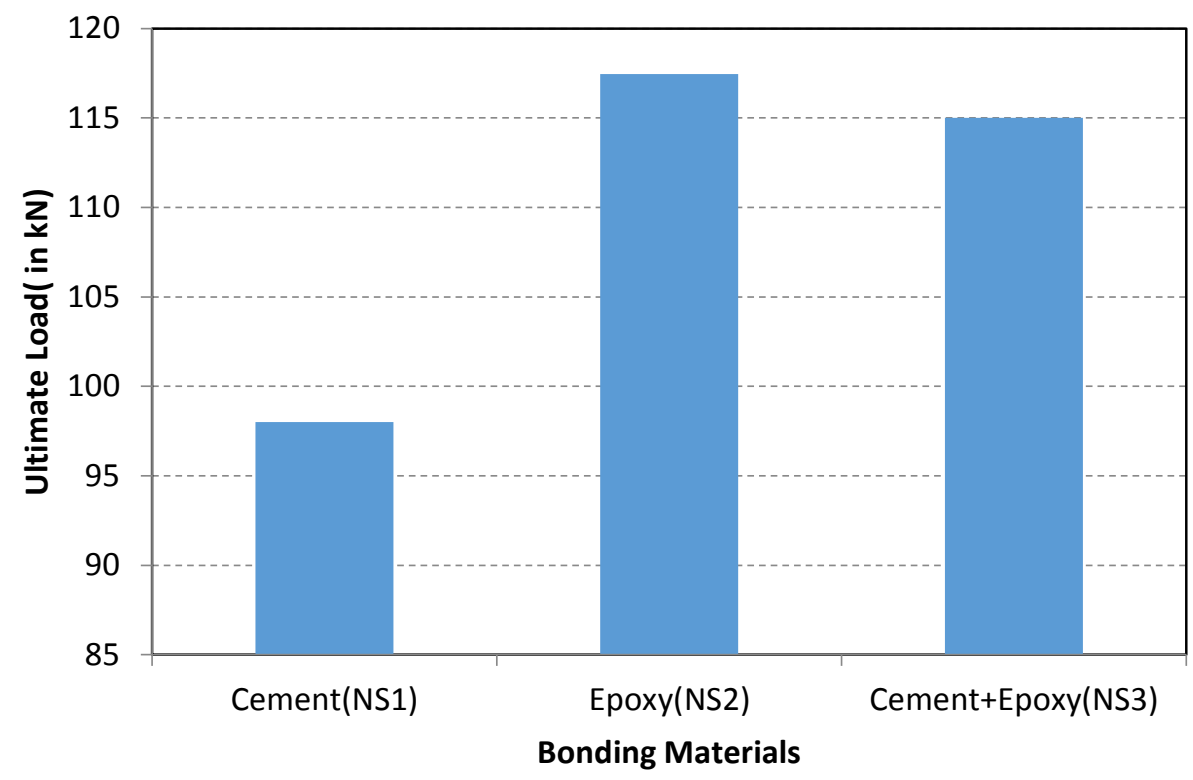

- Ultimate Load(in kN)

\section{Effect of number of NSM grooves}

One groove is required for one bar placing into the concrete. Thus, the number of bars is equal to number of grooves. Fig. 7 shows the effect of number of grooves $s$ on the performance of NSM strengthening technique. The NS1 and NS5, and NS2 and NS4 specimens were used to investigate the effect of strengthening with cement mortar and epoxy adhesive respectively. The amount of strengthening reinforcement is almost similar $\left(56 \mathrm{~mm}^{2}\right)$.

Fig. 7: The effect of number of grooves. Source: Self-Elaboration (2015)

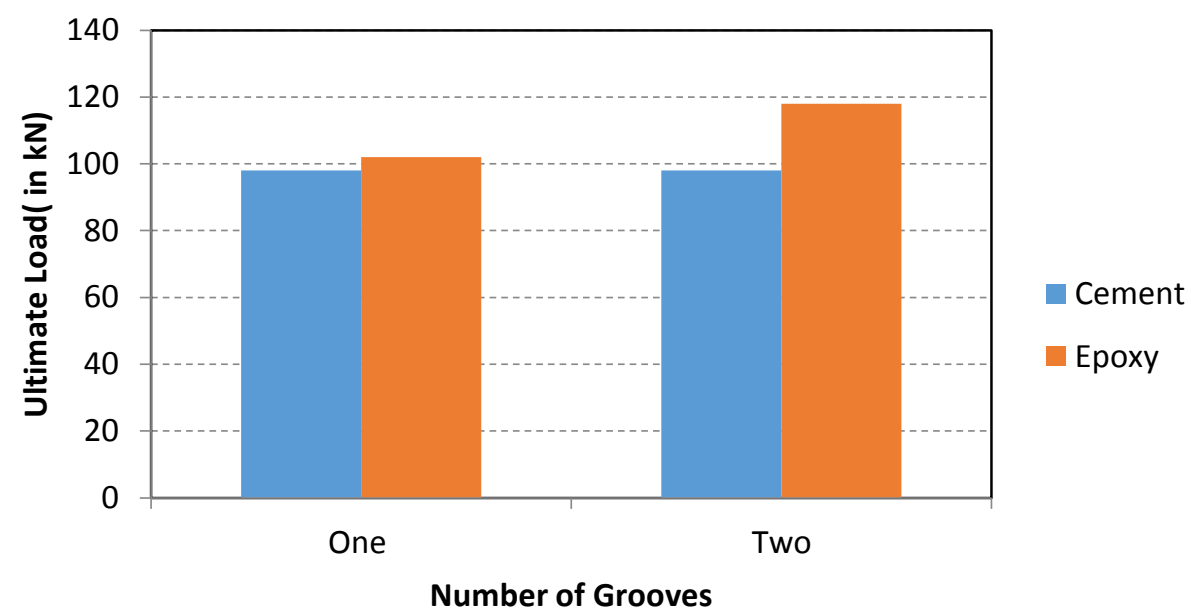

According to Fig. 7, the ultimate load increased with the number of grooves for the case of epoxy strengthened beam due to increasing the volume of adhesive. By contrast of cement mortar, the ultimate load were almost same. Fig. 8 shows the effect of strengthening with cement mortar and epoxy on the load-deflection behavior. 
Fig. 8: Load-Deflection diagram of CB, NS2, NS4 and NS5. Source: Self-Elaboration (2015)

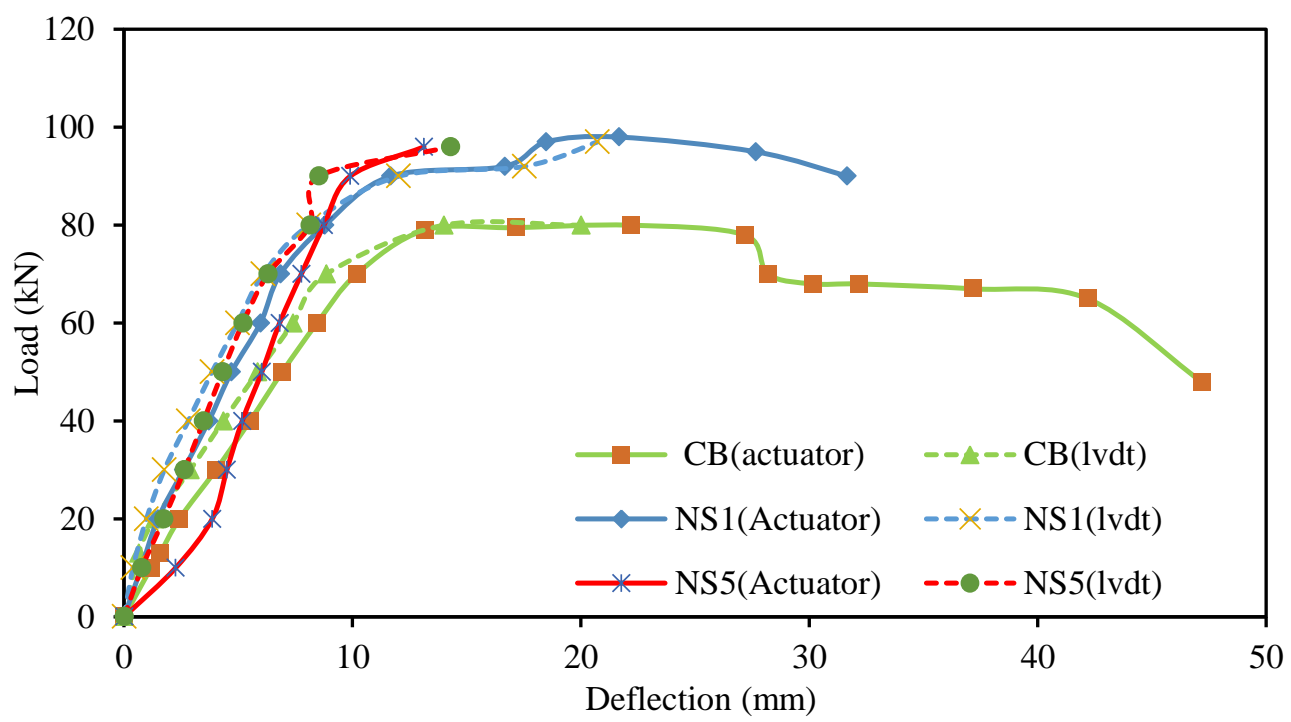

8 (a) Strengthening with cement mortar

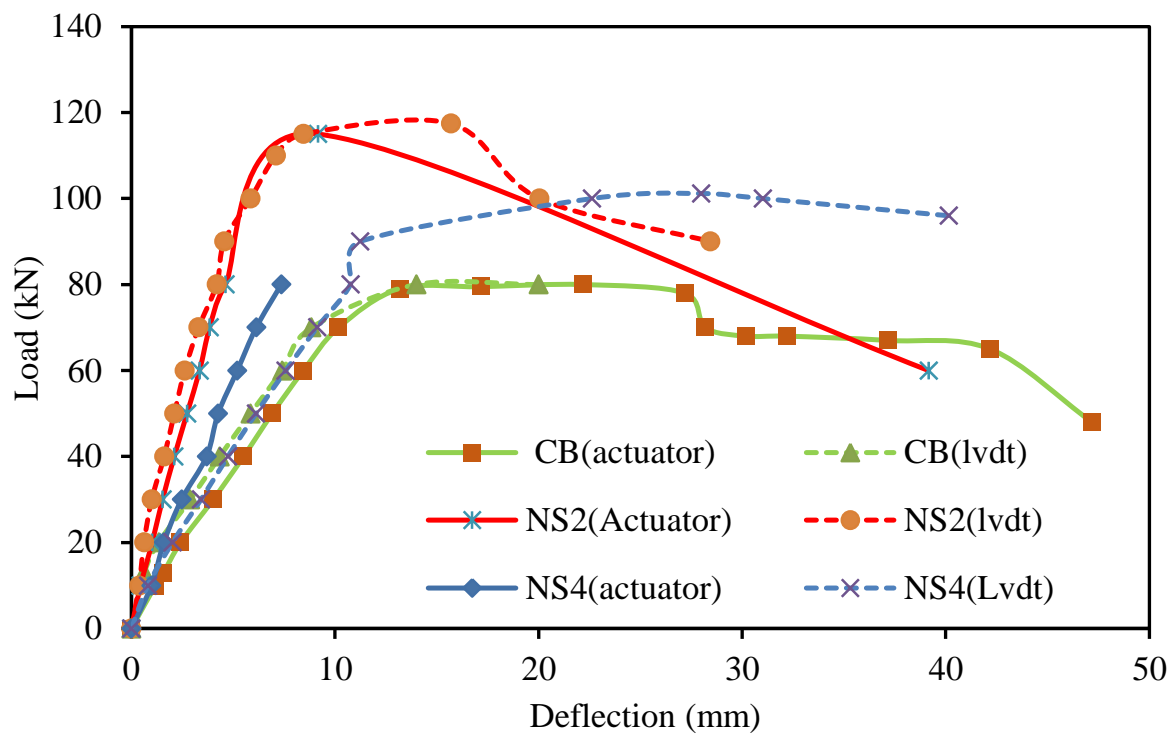

8 (b) Strengthening with epoxy

\section{Effect of bar number with same size}

The amount of reinforcement is the important parameter for flexure strengthening of reinforced concrete beam. Though increase in bar number provides additional reinforcing in concrete beam it decreases both edge clearance and clear spacing of two adjacent grooves. Subsequently the possibility of edge breaking is increased. The beam specimens used in this study might have not enough width to place two $8 \mathrm{~mm}$ bars according to $\mathrm{ACl} 440$ (2008). For this reason in NS6, three $8 \mathrm{~mm}$ bar were placed at different position (one at bottom and two at opposite sides as shown in Fig.2). 
Fig. 9: The effect of bar number on the performance of NSM strengthened beam. Source: Self-Elaboration (2015)

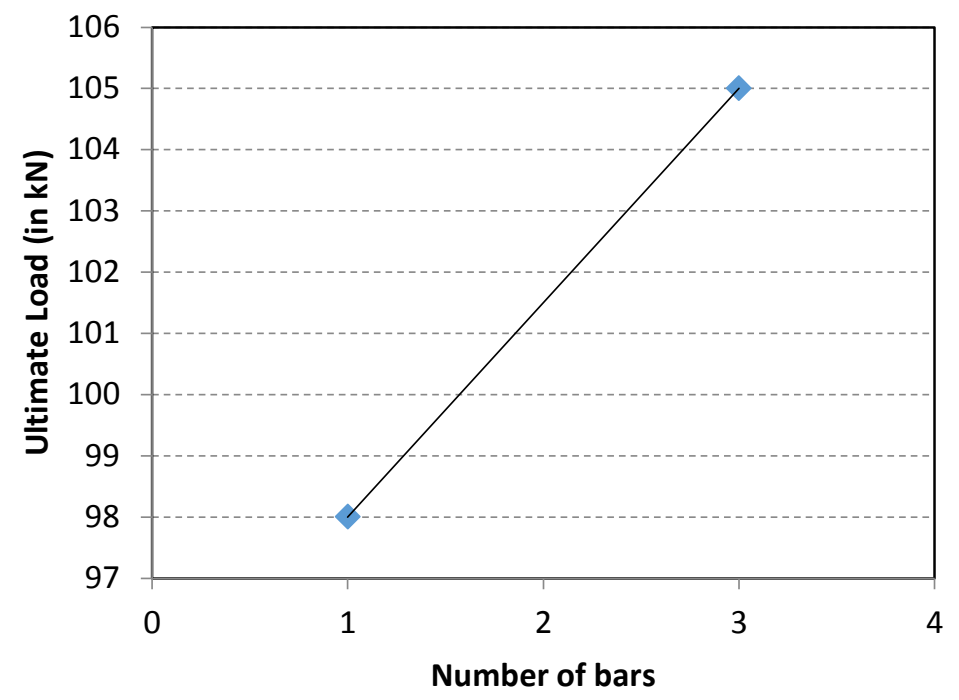

Fig. 9 shows the effect of number of bars on failure behavior of reinforced concrete beam strengthened with NSM steel bar using cement mortar as adhesive. The beam NS5 and NS6 are used to observe this effect.

\section{Comparison with plate bonding method}

Compared to the externally bonded FRP reinforcement (Fig. 10), the NSM system has a number of advantages: (a) the amount of site installation work may be reduced, as surface preparation other than grooving is no longer required (e.g., plaster removal is not necessary; irregularities of the concrete surface can be more easily accommodated; removal of the weak laitance layer on the concrete surface is no longer needed); (b) NSM reinforcement is less prone to debonding from the concrete substrate; (c) NSM bars can be more easily anchored into adjacent members to prevent debonding failures.

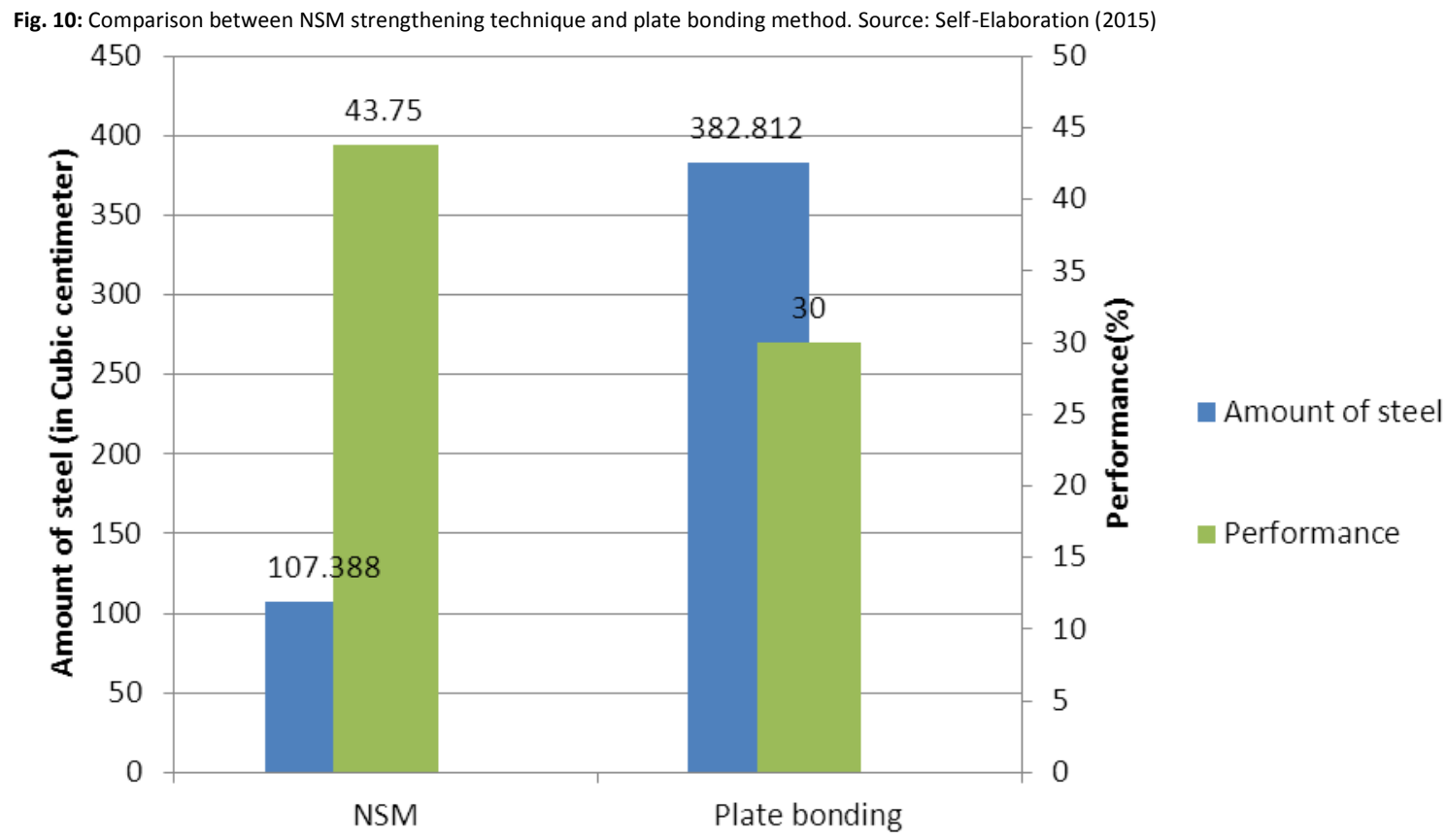

Strengthening Method 
There is a significant potential for NSM steel bar with cement mortar for use in strengthening of RC beams to cost savings in retrofitting structural elements. Based on the experimental study, the following conclusions can be made.

1) Strengthening of RC structures with NSM steel bars is a feasible and economic alternative technique for strengthening structural elements.

2) Cement mortar can be used as groove filler of strengthening reinforced concrete elements with steel bars efficiently.

3) Partial replacement of epoxy by cement mortar could be possible without significantly affecting flexure performance of reinforced concrete beams strengthened with NSM technique.

4) Replacement of $50 \%$ epoxy adhesive by cement mortar in middle portion of NSM groove gives almost similar flexure performance compared to the $100 \%$ epoxy adhesive.

5) Epoxy replacement with cement mortar is most economical alternative for strengthening reinforced concrete beam with NSM strengthening technique.

6) Flexural performance of NSM strengthening is quite better that that of corresponding plate method while the requirement of steel for strengthening with NSM technique is significantly lower(on- third) than that of plate bonding method.

7) Thorough parametric studies show the effectiveness of NSM technique with low cost materials such as adhesive and steel bars.

\section{Acknowledgement}

The authors gratefully acknowledge the financial support from University of Malaya under the University of Malaya Research Grant (UMRG), Grant No. RP018/2012A

Aldana, J., \& Serpell, A. (2012). Temas y tendencias sobre residuos de construcción y demolición: un metaanálisis. Revista de La Construcción, 11(2), 04-16. http://doi.org/10.4067/S0718-915X2012000200002

Al-Mahmoud, F., Castel, A., François, R., \& Tourneur, C. (2009). Strengthening of RC members with near-surface mounted CFRP rods. Composite Structures, 91(2), 138-147. http://doi.org/10.1016/j.compstruct.2009.04.040

Asplund, S. O. (1949). Strengthening Bridge Slabs with Grouted Reinforcement. Journal of American Concrete Institute, 45(1), $397-406$.

Badawi, M., \& Soudki, K. (2009). Flexural strengthening of RC beams with prestressed NSM CFRP rods - Experimental and analytical investigation. Construction and Building Materials, 23(10), 3292-3300. http://doi.org/10.1016/j.conbuildmat.2009.03.005

Bilotta, A., Ceroni, F., Nigro, E., \& Pecce, M. (2015). Efficiency of CFRP NSM strips and EBR plates for flexural strengthening of RC beams and loading pattern influence. Composite Structures, 124, 163-175. http://doi.org/10.1016/j.compstruct.2014.12.046

Cárdenas, M., Schanach, F., \& Ramos, O. (2010). Diseño , construcción y ensayo de una estructura de sección mixta madera laminada-hormigón para su uso en puentes. Revista de La Construcción, 9(2), 63-75.

De Lorenzis, L., Nanni, a., \& La Tegola, a. (2000). Flexural and Shear Strengthening of Reinforced Concrete Structures with Near Surface Mounted FRP Rods. In J. Humar (Ed.), Advanced Composite Materials in Bridges and Structures, Proc. of 3rd Int. (pp. 521- 528). Milan, Italy.

De Lorenzis, L., \& Teng, J. G. (2007). Near-surface mounted FRP reinforcement: An emerging technique for strengthening structures. Composites Part B: Engineering, 38(2), 119-143. http://doi.org/10.1016/j.compositesb.2006.08.003

El-Hacha, R. and Rizkalla, S. H. (2004). Near-Surface-Mounted Fiber-Reinforced Polymer Reinforcements for Flexural Strengthening of Concrete Structures. ACl Structural Journal, 101(5), 717-726.

El-Hacha, R., \& Gaafar, M. (2011). Flexural strengthening of reinforced concrete beams using prestressed, near-surface-mounted CFRP bars. PCI Journal, 56(4), 134-151.

Garrity, S. W. (2001). Near-surface reinforcement of masonry arch highway bridges. In Proceedings of the 9th Canadian Masonry Symposium. Fredericton (Canada).

Hanson, J. M., Somes, N. F., \& Helgason, T. (1974). Investigation Affecting Reinforcing of Design Factors Fatigue Strength of Program Fatigue Bars Test Factors. ACI Special Publication, (SP-41), 107-137.

Hassan, T., \& Rizkalla, S. (2001). Cost-Effectiveness of Various FRP Repair Techniques for RC Structures. In Proceedings of the International Workshop on Structural Composites for Infrastructural Application (pp. 41-55). Cairo, Egypt.

Hosen, M. A., Jumaat, M. Z., \& Islam, A. B. M. S. (2015). Side Near Surface Mounted (SNSM) technique for flexural enhancement of RC beams. Materials \& Design, 83, 587-597. http://doi.org/10.1016/j.matdes.2015.06.035

Huang, Y., Wu, J., Yen, T., Hung, C., \& Lin, Y. (2005). Strengthening reinforced concrete beams using prestressed glass fiber-reinforced polymer-Part I: Experimental study. Journal of Zhejiang University SCIENCE, 6A(3), 166-174. http://doi.org/10.1631/jzus.2005.A0166

Islam, A. B. M. S., Jameel, M., Jumaat, M. Z., \& Rahman, M. M. (2013). Optimization in structural altitude for seismic base isolation at medium risk earthquake disaster region. Disaster Advances, 6(1), 23-34.

Lorenzis, L. De, \& Nanni, A. (2002). Strengthening of RC structures with near-surface mounted FRP rods. Report. University of Lecce, Italy.

Moss, D. S. (1982). Bending fatigue of high-yield reinforcing bars in concrete. Transport and Road Research Laboratory,Crowthome, U.K.

NATIONAL RESEARCH COUNCIL. (2004). Guide for the design and construction of externally bonded FRP systems for strengthening existing structures. ACl 440.2R-02, ACl, Farmington Hills, Michigan: CNR - Advisory Committee on Technical Recommendations for Construction.

Rahal, K. N., \& Rumaih, H. a. (2011). Tests on reinforced concrete beams strengthened in shear using near surface mounted CFRP and steel bars. Engineering Structures, 33(1), 53-62. http://doi.org/10.1016/j.engstruct.2010.09.017

Rahman, M. M., Jumaat, M. Z., Rahman, M. A., \& Qeshta, I. M. I. (2015). Innovative hybrid bonding method for strengthening reinforced concrete beam in flexure. Construction and Building Materials, 79, 370-378. http://doi.org/10.1016/j.conbuildmat.2014.12.081

Soliman, S. M., El-Salakawy, E., \& Benmokrane, B. (2010). Flexural behaviour of concrete beams strengthened with near surface mounted fibre reinforced polymer bars. Canadian Journal of Civil Engineering, 37(10), 1371-1382. http://doi.org/10.1139/L10-077

Taljsten, B., \& Carolin, A. (2003). Concrete structures strengthened with near surface mounted reinforcement of CFRP. Advanced Structural Engineering, 6(3), 201-2014.

Toutanji, H., Zhao, L., \& Zhang, Y. (2006). Flexural behavior of reinforced concrete beams externally strengthened with CFRP sheets bonded with an inorganic matrix. Engineering Structures, 28(4), 557-566. http://doi.org/10.1016/j.engstruct.2005.09.011

Wang, H., Jin, W., Cleland, D. J., \& Zhang, A. (2009). Strengthening an in-service reinforcement concrete bridge with prestressed CFRP bar. Journal of Zhejiang University SCIENCE A, 10(5), 635-644. http://doi.org/10.1631/jzus.A0820836 